\title{
Variation Among Creeping Bentgrass Cultivars in Recovery from Epidemics of Dollar Spot
}

\author{
P. Vincelli, and J. C. Doney, Jr., Department of Plant Pathology, and A. J. Powell, Department of Agronomy, Uni- \\ versity of Kentucky, Agricultural Science Center-North, Lexington 40546-0091
}

\begin{abstract}
Vincelli, P., Doney, J. C., Jr., and Powell, A. J. 1997. Variation among creeping bentgrass cultivars in recovery from epidemics of dollar spot. Plant Dis. 81:99-102.

Dollar spot was allowed to develop from natural inoculum in 15 cultivars of creeping bentgrass (Agrostis palustris) until epidemics were well established. At that time, initial disease intensities were assessed, and one-half of each plot was treated with cyproconazole at $0.3 \mathrm{~kg}$ a.i./ha. For each cultivar, disease intensities were assessed 6 to 14 days after treatment in both treated and untreated subplots. Three general patterns of recovery were observed: (i) significant recovery only with fungicide treatment; (ii) some recovery without treatment but greater recovery with treatment; and (iii) equal recovery with or without treatment. Only one cultivar exhibited the same recovery pattern in all 3 years; 10 of 15 cultivars exhibited the same pattern in 2 years of testing. In 1991 and 1993, nearly all cultivars tested recovered more quickly when treated with cyproconazole than when left untreated. In contrast, nearly half of the cultivars in 1992 exhibited the same level of recovery in both treated and untreated subplots. Weather conditions during the 1992 test period were cooler and wetter than during the other years of the study, which probably favored host growth and turfgrass recovery. While some cultivars exhibited partial resistance to dollar spot, no consistent association was found among creeping bentgrass cultivars between the level of partial resistance to, and recuperative ability from, dollar spot. Although the recuperative potential of cultivars varies in different environments, the ability to recover quickly from a disease outbreak could be a valuable cultivar attribute, particularly if it can sometimes occur without a curative fungicide application.
\end{abstract}

Additional keyword: Agrostis stolonifera

Research data exist on differences in susceptibility of turfgrass cultivars to various pathogens, particularly for cultivars included in the National Turfgrass Evaluation Program (1-3). Evaluations of turfgrass disease resistance typically are based on comparisons of disease intensities among cultivars at one or more assessment times. While these data are valuable, relatively few published reports exist where turfgrass cultivars were evaluated for recovery (postepidemic vegetative regrowth of symptomless tissue) (5) following a disease outbreak. Model studies conducted to date $(5,14)$ have focused on turfgrass recovery in the absence of curative fungicide applications. Although quick recovery without fungicide is preferable, knowledge of how turfgrass cultivars perform following fungicide application could also be important for management regimes where fungicides are used. This could be particu-

Corresponding author: P. Vincelli

E-mail: pvincell@ca.uky.edu

Paper 95-12-187 of the Journal Series of the Kentucky Agricultural Experiment Station.

Accepted for publication 13 September 1996.

Publication no. D-1996-1126-04R

(C) 1997 The American Phytopathological Society larly important in implementing turfgrass integrated pest management programs, whereby certain diseases may be allowed to develop until some action threshold before a curative fungicide application is made.

Dollar spot, caused by Sclerotinia homoeocarpa $\mathrm{F}$. T. Bennett, is a common and destructive disease of creeping bentgrass (Agrostis palustris Huds.) (17,19). Although cultivars vary in their susceptibility, none is considered completely resistant to S. homoeocarpa (19). A severe dollar spot outbreak can affect the quality of playing surfaces, influence aesthetic appearance, allow weed encroachment in turfgrass swards, and even cause plant death (18).

The reactions of many creeping bentgrass cultivars to $S$. homoeocarpa have been well characterized in recent years (1$3,8,10,11)$. However, published studies where creeping bentgrass cultivars were evaluated for recovery from disease outbreaks are lacking. Knowledge of the recuperative potential of creeping bentgrass cultivars would be valuable in implementing an integrated disease management program on golf courses.

This paper reports the results of field studies to evaluate bentgrass cultivars for recovery following outbreaks of dollar spot in both the absence and the presence of a curative fungicide application. Although the study included entries of four Agrostis spp., this paper reports results obtained for creeping bentgrass, the most widely used bentgrass species in the United States. Preliminary reports for all four Agrostis spp. are available $(9,12)$.

\section{MATERIALS AND METHODS}

Cultural conditions. Twenty cultivars (commercially cultivated as well as experimental lines) of four species of bentgrass (Agrostis spp.) were established in a Maury silt loam at the University of Kentucky Spindletop Research Farm as part of the 1989 National Bentgrass Fairways and Tees Evaluation. The number of entries and species represented were the following: 15 entries of A. palustris, one entry of A. capillaris L. (browntop bentgrass), one of A. castellana Boiss. \& Reut. (dryland bentgrass), and three of A. tenuis Sibth. (colonial bentgrass). Entries were seeded at $25 \mathrm{~kg} / \mathrm{ha}$ on 21 September 1989 in plots measuring $2.4 \times 3.7 \mathrm{~m}$ and arranged in a randomized complete block design with three replicates. Two autumn applications of urea $(73 \mathrm{~kg} \mathrm{~N} / \mathrm{ha}$ at each application) were made annually after establishment; acceptable turfgrass quality was maintained without additional fertilizer applications. Plots were maintained at a height of $1.3 \mathrm{~cm}$ and were irrigated as necessary. Weather conditions were monitored at the UK Spindletop Agricultural Weather Station located within $100 \mathrm{~m}$ of the test site.

Evaluation of recovery. Dollar spot developed from natural inoculum until epidemics were well established (initial disease intensities provided in data tables). In 1991 and 1993, each plot was bisected into two $1.8 \times 2.4 \mathrm{~m}$ subplots, and the initial disease intensity was assessed by counting infection centers in three randomly placed $929 \mathrm{~cm}^{2}$ quadrats in each subplot. In 1992, pretreatment disease intensity was assessed by counting infection centers in one randomly placed quadrat within each subplot and in one quadrat along the line bisecting the whole plot. These three observations were averaged prior to analysis to provide an estimate of the initial disease intensity for each whole plot. The eastern (1991 and 1993) or western (1992) subplot of each plot was treated within $24 \mathrm{~h}$ with the ergosterol biosynthesis inhibitor fungicide cyproconazole at $0.76 \mathrm{~kg}$ a.i./ha (Sentinel $40 \mathrm{WDG}$ ) in 1,018 liters of water per ha using a hand-held sprayer fitted with 8003E nozzles (Spraying Systems, Inc., 
Baltimore, MD). Infection centers were counted again in each subplot 6 to 14 days posttreatment. Data for separate quadrats within each subplot were averaged for each assessment date prior to analysis.

Data analysis. To assess recovery from dollar spot, disease intensity estimates for each cultivar were analyzed independently in each experiment. Data were analyzed by cultivar using analysis of variance for a randomized complete block design after first checking appropriate statistical assumptions. For each cultivar, posttreatment disease intensities in both treated and nontreated subplots were compared with each other and with initial disease intensities using the Waller-Duncan $k$-ratio $t$ test (16).

In 1992, initial pretreatment disease intensities taken from the whole plot were compared to posttreatment estimates taken from each subplot. In order to evaluate the validity of this analysis, data on initial disease intensity for the entire experiment in both 1991 and 1993 were analyzed following a split block design (13); main plots were replicate and cultivar, and the strip plot was subplot position (east versus west). The main effect for position and the interaction term for cultivar $\times$ position were used to test the hypothesis that subplot position had an effect on dollar spot intensity.

Recuperative potential of a cultivar from dollar spot was expressed as a percentage of disease intensity at the start of each experiment, \%RECOV $V_{t}=\left[\left(D I_{0}-D I_{t}\right) / D I_{0}\right] 100$, where $\% R E C O V_{t}=$ percent recovery on day $t, D I_{0}=$ mean initial disease intensity and $D I_{t}=$ mean disease intensity on day $t$. Scatter plots and linear regression models (15) were evaluated to test for relationships between the level of partial resistance to dollar spot (as measured by $D I_{0}$ ) and recuperative potential $\left(\% R E C O V_{t}\right)$. Separate regression analyses were conducted for fungicide-treated and untreated subplots for all posttreatment assessment dates.

\section{RESULTS}

1991 experiment. Several cultivarsLopez, National, Penncross, Penneagle, Pro/Cup, Providence, and $88 \mathrm{CBE}-$ showed significant $(P \leq 0.05)$ recovery over a 10-day period only when treated with cyproconazole (Table 1). During the same period, significant recovery without fungicide was exhibited by Cobra, Regent, and SR 1020, but even greater recovery $(P$

Table 1. Recovery of creeping bentgrass cultivars from outbreaks of dollar spot during 1991

\begin{tabular}{|c|c|c|c|c|}
\hline \multirow[b]{3}{*}{ Cultivar } & \multicolumn{4}{|c|}{ Number of infection centers per $\mathbf{m}^{2}$} \\
\hline & \multicolumn{2}{|c|}{1 August 91} & \multicolumn{2}{|c|}{11 August 91} \\
\hline & $\begin{array}{l}\text { West subplot } \\
\text { (untreated) }\end{array}$ & $\begin{array}{l}\text { East subplot } \\
\text { (untreated) }\end{array}$ & $\begin{array}{l}\text { West subplot } \\
\text { (untreated) }\end{array}$ & $\begin{array}{c}\text { East subplot } \\
\text { (treated } 2 \text { Aug) }\end{array}$ \\
\hline Lopez & $222 a^{z}$ & $183 \mathrm{a}$ & $193 \mathrm{a}$ & $42 \mathrm{~b}$ \\
\hline National & $119 a$ & $105 \mathrm{a}$ & $88 \mathrm{a}$ & $13 \mathrm{~b}$ \\
\hline Penncross & $208 \mathrm{a}$ & $244 \mathrm{a}$ & $173 \mathrm{a}$ & $19 \mathrm{~b}$ \\
\hline Penneagle & $244 \mathrm{a}$ & $228 \mathrm{a}$ & $195 \mathrm{a}$ & $19 \mathrm{~b}$ \\
\hline Pro/Cup & 198 a & $198 \mathrm{a}$ & $224 \mathrm{a}$ & $40 \mathrm{~b}$ \\
\hline Providence & $191 \mathrm{a}$ & $189 \mathrm{a}$ & $143 \mathrm{a}$ & $31 \mathrm{~b}$ \\
\hline $88 \mathrm{CBE}$ & $118 \mathrm{a}$ & $149 \mathrm{a}$ & $148 \mathrm{a}$ & $15 \mathrm{~b}$ \\
\hline Cobra & $184 \mathrm{a}$ & $174 \mathrm{a}$ & $93 \mathrm{~b}$ & $9 \mathrm{c}$ \\
\hline Regent & $192 \mathrm{a}$ & $182 \mathrm{a}$ & $125 \mathrm{~b}$ & $33 c$ \\
\hline SR 1020 & $243 \mathrm{a}$ & $216 \mathrm{a}$ & $108 \mathrm{~b}$ & $17 \mathrm{c}$ \\
\hline Carmen & $225 \mathrm{a}$ & $252 \mathrm{a}$ & $126 \mathrm{ab}$ & $15 \mathrm{~b}$ \\
\hline Emerald & $212 \mathrm{a}$ & $170 \mathrm{ab}$ & $93 \mathrm{bc}$ & $22 \mathrm{c}$ \\
\hline Viper & $189 a$ & $157 \mathrm{~b}$ & $136 \mathrm{~b}$ & $14 \mathrm{c}$ \\
\hline Putter & $228 \mathrm{a}$ & $209 a$ & $87 \mathrm{~b}$ & $34 \mathrm{~b}$ \\
\hline TAMU 881 & $173 \mathrm{a}$ & $203 \mathrm{a}$ & $60 \mathrm{~b}$ & $2 b$ \\
\hline
\end{tabular}

y Subplots treated on 2 August with $0.3 \mathrm{~kg}$ of cyproconazole per ha.

${ }^{\mathrm{z}}$ Means within a row (=cultivar) followed by the same letter are not significantly different using the Waller-Duncan $k$-ratio $t$ test $(k=100, P=0.05)$.

Table 2. Analysis of variance of pretreatment data on intensity of dollar spot in 20 bentgrass cultivars

\begin{tabular}{lccc}
\hline & & \multicolumn{2}{c}{ Mean squares $^{\mathbf{y}}$} \\
\cline { 3 - 4 } Source & df & $\mathbf{1 9 9 1}$ & $\mathbf{1 9 9 3}$ \\
\hline Replicate & 2 & 24.31 & 205.4 \\
Cultivar & 19 & $297.2^{* *}$ & $227.8^{* *}$ \\
Rep $\times$ cultivar (error a) & 38 & 26.52 & 14.87 \\
Position & 1 & 0.0750 & 75.21 \\
Rep $\times$ position (error b) & 2 & 18.20 & 29.72 \\
Cultivar $\times$ position & 19 & 7.786 & 7.458 \\
Experimental error (error c) & 38 & 8.590 & 6.840 \\
Total & 119 & & \\
\hline
\end{tabular}

y $* *=P \leq 0.01$.

${ }^{\mathrm{z}}$ Data were collected separately for the eastern and western sides of each plot.

$\leq 0.05)$ was observed in these cultivars with cyproconazole treatment. Carmen, Emerald, and Viper exhibited similar responses to those described above, but they were not readily characterized because of the overlap of statistical groupings among treatment means. Putter and TAMU 881 exhibited statistically equivalent levels of recovery with or without fungicide treatment. The median daily maximum air temperature and total rainfall during the 10day test period were $32.2^{\circ} \mathrm{C}$ and $1.1 \mathrm{~cm}$, respectively.

1992 experiment. The lack of significant effects for position and cultivar $x$ position $(P>0.20)$ in the initial disease intensity data collected during 1991 and 1993 (Table 2) validated the acceptability of comparing data collected for whole plots on 3 August 1992 with data collected from subplots on 11 August 1992 and 17 August 1992. Two weeks after treatment, Lopez, Pro/Cup, and Putter exhibited significant recovery only where fungicide was applied (Table 3). Penneagle and SR 1020 exhibited significant recovery without fungicide, but even greater recovery was observed with cyproconazole treatment. Cobra, Emerald, National, Regent, TAMU 881, Viper, and $88 \mathrm{CBE}$ exhibited statistically equivalent levels of recovery in both fungicide-treated and nontreated subplots, although disease levels in Emerald and TAMU 881 after the 2-week period of study were higher than would be acceptable for a high-quality sward. Carmen and Penncross did not exhibit statistically significant recovery after 2 weeks, even when treated with cyproconazole; high variability in disease intensity may have contributed to the lack of significant differences in these two cultivars. The response of Providence was not readily characterized because of overlap of statistical groupings among treatment means. The median daily maximum air temperature and total rainfall during the 14-day test period were $26.7^{\circ} \mathrm{C}$ and $7.4 \mathrm{~cm}$, respectively.

1993 experiment. Twelve of 15 cultivars exhibited no significant change in disease intensity without fungicide, and none exhibited recovery to acceptably low levels without fungicide during the 13-day test period (Table 4). Pro/Cup and SR 1020 exhibited some statistically significant recovery without fungicide but required fungicide treatment to recover to levels during the test period that would be acceptable for high-maintenance swards. In untreated subplots of the cultivar National, disease intensity increased during the test period, the only instance where this was observed during our study. The median daily maximum air temperature and total rainfall during the 13-day test period were $31.1^{\circ} \mathrm{C}$ and $3.0 \mathrm{~cm}$, respectively.

Test of association between partial resistance and recovery. No consistent relationship was observed between the level of partial resistance to dollar spot and recu- 
perative potential as measured by the vari-

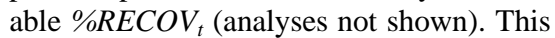
was the case in both fungicide-treated and untreated subplots.

\section{DISCUSSION}

During these studies, three general patterns of recovery from dollar spot outbreaks were commonly observed among creeping bentgrass cultivars: (i) significant recovery during the test period only with fungicide treatment; (ii) some statistically significant recovery without treatment but significantly greater recovery with fungicide treatment; and (iii) statistically equivalent recovery with or without fungicide treatment. In a few cases, certain cultivars showed no recovery or even exhibited an increase in dollar spot intensity in plots not treated with fungicide.

Environmental conditions affected the ability of creeping bentgrass cultivars to recover from dollar spot. In 1991 and 1993, nearly all cultivars tested recovered more quickly when treated with cyproconazole than when left untreated. In contrast, nearly half of the cultivars in 1992 exhibited the same level of recovery in both fungicide-treated and untreated subplots. Weather conditions during the 1992 test period were cooler and wetter than in other years of the study, which may have favored growth and recovery of this coolseason turfgrass. The temperatures observed in 1992 were more favorable for shoot and root growth of creeping bentgrass than those recorded in 1991 and 1993 $(4,7)$. Adequate soil moisture may have also played a role in the quick recovery observed in 1992. Although the trial was irrigated as needed, temporary drought conditions developed occasionally during the warmer, drier conditions that occurred in 1991 and 1993. Such stress would have favored continued disease development during the 1991 and 1993 test periods (6,17-19), necessitating fungicide protection in many cultivars.

In 1992, pretreatment disease intensities taken from whole plots were compared to posttreatment estimates taken from the treated and untreated subplots. Although there was no effect of subplot position (east versus west) on disease intensity, we concluded that the experimental approach taken in 1991 and 1993-that is, separate pretreatment estimates of disease intensity for each subplot-is preferable for evaluating varietal recovery following a curative fungicide application. Even in the absence of evidence for a position effect in the analysis of variance, one cultivar in 1991 (Viper) and another in 1993 (Providence) exhibited different pretreatment disease levels in eastern versus western subplots. We concluded that these exceptions were probably due to natural variability in the occurrence of dollar spot, and that they did not negate the overall value of the 1992 data. Nevertheless, a more critical evalua- tion of a cultivar's recovery potential with and without fungicide is possible if pretreatment estimates are available for both treated and untreated subplots.

We observed no consistent association between the level of partial resistance to $S$. homoeocarpa and recuperative potential among the 15 cultivars tested. This result indicates that the ability to recover from dollar spot is not directly related to the ability of creeping bentgrass cultivars to restrict pathogen activity and disease development. Cultivars exhibiting high recuperative potential may combine a high rate of foliar growth with partial resistance to $S$. homoeocarpa, a hypothesis worth testing in future studies on recovery of turfgrass cultivars from disease. The relatively rapid recovery we observed suggests healthy tillers and leaves were being produced by surviving crowns and stolons, although detailed studies to understand how recovery occurs in creeping bentgrass would be useful. It would be of interest to know whether cultivars that exhibit quick recovery have a higher density of live crowns and/or stolons, more aggressive stoloniferous growth into diseased areas, or more rapid production of foliage from crowns. Furthermore, knowledge of the role of partial resistance in promoting recovery would be valuable. We concur with Burpee (5) that recovery of turfgrasses from a disease outbreak is a manifestation of disease tolerance rather than host plant resistance, since recuperative potential did not show a consistent association with the level of partial resistance.

Table 3. Recovery of creeping bentgrass cultivars from outbreaks of dollar spot during 1992

\begin{tabular}{|c|c|c|c|c|c|}
\hline \multirow[b]{3}{*}{ Cultivar } & \multicolumn{5}{|c|}{ Number of infection centers per $\mathbf{m}^{2}$} \\
\hline & \multirow{2}{*}{$\begin{array}{c}3 \text { Aug } 92 \\
\text { (whole plot } \\
\text { measurement) }\end{array}$} & \multicolumn{2}{|c|}{11 Aug 92} & \multicolumn{2}{|c|}{17 Aug 92} \\
\hline & & $\begin{array}{c}\begin{array}{c}\text { West subplot } \\
\text { (untreated) }\end{array} \\
\end{array}$ & $\begin{array}{c}\text { East subplot } \\
\text { (treated 4 Aug)y }\end{array}$ & $\begin{array}{c}\begin{array}{c}\text { West subplot } \\
\text { (untreated) }\end{array} \\
\end{array}$ & $\begin{array}{c}\text { East subplot } \\
\text { (treated } 4 \text { Aug) }\end{array}$ \\
\hline Lopez & $72 \mathrm{a}^{\mathrm{z}}$ & $43 \mathrm{ab}$ & $18 \mathrm{ab}$ & $55 \mathrm{ab}$ & $10 \mathrm{~b}$ \\
\hline Pro/Cup & $155 \mathrm{a}$ & $32 \mathrm{~b}$ & $18 \mathrm{~b}$ & $50 \mathrm{ab}$ & $34 \mathrm{~b}$ \\
\hline Putter & $99 \mathrm{a}$ & $61 \mathrm{bc}$ & $25 \mathrm{~cd}$ & $68 \mathrm{ab}$ & $19 \mathrm{~d}$ \\
\hline Penneagle & $60 \mathrm{a}$ & $29 \mathrm{bc}$ & $18 \mathrm{bc}$ & $36 \mathrm{~b}$ & $11 \mathrm{c}$ \\
\hline SR 1020 & $139 a$ & $72 \mathrm{bc}$ & $40 \mathrm{~cd}$ & $101 \mathrm{~b}$ & $28 \mathrm{~d}$ \\
\hline Cobra & $64 \mathrm{a}$ & $22 a b$ & $18 \mathrm{~b}$ & $14 \mathrm{~b}$ & $3 \mathrm{~b}$ \\
\hline Emerald & $235 \mathrm{a}$ & $75 \mathrm{~b}$ & $57 \mathrm{~b}$ & $139 \mathrm{~b}$ & $80 \mathrm{~b}$ \\
\hline National & $25 \mathrm{a}$ & $18 \mathrm{ab}$ & $11 \mathrm{bc}$ & $3 \mathrm{~cd}$ & $0 \mathrm{~d}$ \\
\hline Regent & $46 \mathrm{a}$ & $18 \mathrm{~b}$ & $14 \mathrm{~b}$ & $18 \mathrm{~b}$ & $6 \mathrm{~b}$ \\
\hline TAMU 881 & 209 a & $154 a b$ & $97 \mathrm{bc}$ & $103 b c$ & $47 \mathrm{c}$ \\
\hline Viper & $42 \mathrm{a}$ & $25 \mathrm{~b}$ & $18 \mathrm{bc}$ & $9 \mathrm{~cd}$ & $2 d$ \\
\hline $88 \mathrm{CBE}$ & $52 \mathrm{a}$ & $36 \mathrm{ab}$ & $29 \mathrm{ab}$ & $10 \mathrm{~b}$ & $1 \mathrm{~b}$ \\
\hline Carmen & $105 \mathrm{a}$ & $65 \mathrm{a}$ & $36 \mathrm{a}$ & $57 \mathrm{a}$ & $52 \mathrm{a}$ \\
\hline Penncross & $128 \mathrm{a}$ & $46 \mathrm{ab}$ & $36 \mathrm{~b}$ & $78 \mathrm{ab}$ & $40 \mathrm{ab}$ \\
\hline Providence & $45 \mathrm{ab}$ & $40 \mathrm{ab}$ & $18 \mathrm{ab}$ & $62 \mathrm{a}$ & $4 \mathrm{~b}$ \\
\hline
\end{tabular}

y Subplots treated on 4 August with $0.3 \mathrm{~kg}$ of cyproconazole per ha.

${ }^{\mathrm{z}}$ Means within a row (=cultivar) followed by the same letter are not significantly different using the Waller-Duncan $k$-ratio $t$ test $(k=100, P=0.05)$.

Table 4. Recovery of creeping bentgrass cultivars from outbreaks of dollar spot during 1993

\begin{tabular}{|c|c|c|c|c|c|c|}
\hline \multirow[b]{4}{*}{ Cultivar } & \multicolumn{6}{|c|}{ Number of infection centers per $\mathbf{m}^{2}$} \\
\hline & & & \multicolumn{2}{|c|}{30 Jun 93} & \multicolumn{2}{|c|}{7 Jul 93} \\
\hline & \multicolumn{2}{|c|}{24 Jun 93} & \multirow{2}{*}{\multicolumn{2}{|c|}{$\begin{array}{cc}\text { West subplot } & \begin{array}{c}\text { East subplot } \\
\text { (treated }\end{array} \\
\text { (untreated) } & \text { 25 Jun)y }\end{array}$}} & \multirow[b]{2}{*}{$\begin{array}{l}\text { West subplot } \\
\text { (untreated) }\end{array}$} & \multirow{2}{*}{$\begin{array}{l}\text { East subplot } \\
\text { (treated } \\
25 \text { Jun) }\end{array}$} \\
\hline & $\begin{array}{l}\text { West subplot } \\
\text { (untreated) }\end{array}$ & $\begin{array}{c}\text { East subplot } \\
\text { (untreated) }\end{array}$ & & & & \\
\hline Carmen & $160 \mathrm{a}^{\mathrm{z}}$ & $189 \mathrm{a}$ & $152 \mathrm{a}$ & $129 \mathrm{a}$ & $142 \mathrm{a}$ & $8 \mathrm{~b}$ \\
\hline Cobra & $110 \mathrm{ab}$ & $139 \mathrm{a}$ & $98 \mathrm{a}$ & $61 \mathrm{bc}$ & $90 \mathrm{ab}$ & $1 \mathrm{c}$ \\
\hline Emerald & $146 \mathrm{abc}$ & $174 \mathrm{a}$ & $155 \mathrm{ab}$ & $101 \mathrm{bc}$ & $83 \mathrm{c}$ & $2 \mathrm{~d}$ \\
\hline Lopez & $163 \mathrm{a}$ & $151 \mathrm{a}$ & $138 \mathrm{a}$ & $103 \mathrm{a}$ & $128 \mathrm{a}$ & $15 \mathrm{~b}$ \\
\hline Penncross & $169 \mathrm{ab}$ & $230 \mathrm{a}$ & $180 \mathrm{ab}$ & $133 \mathrm{~b}$ & $123 \mathrm{~b}$ & $4 \mathrm{c}$ \\
\hline Penneagle & $80 a b$ & $130 \mathrm{a}$ & $89 \mathrm{ab}$ & $39 a b$ & $97 \mathrm{ab}$ & $6 \mathrm{~b}$ \\
\hline Providence & $76 \mathrm{bc}$ & $157 \mathrm{a}$ & $86 a b$ & $89 a b$ & $109 \mathrm{ab}$ & $3 c$ \\
\hline Putter & $131 \mathrm{a}$ & $143 \mathrm{a}$ & $123 \mathrm{a}$ & 99 a & $112 \mathrm{a}$ & $6 \mathrm{~b}$ \\
\hline Regent & $103 \mathrm{a}$ & $90 \mathrm{a}$ & $89 \mathrm{a}$ & $30 \mathrm{~b}$ & $115 \mathrm{a}$ & $2 b$ \\
\hline TAMU 881 & $187 \mathrm{a}$ & $192 \mathrm{a}$ & $180 \mathrm{a}$ & $111 \mathrm{~b}$ & $153 \mathrm{ab}$ & $13 \mathrm{c}$ \\
\hline Viper & $103 \mathrm{a}$ & $107 \mathrm{a}$ & $116 \mathrm{a}$ & $72 \mathrm{a}$ & $104 \mathrm{a}$ & $3 \mathrm{~b}$ \\
\hline $88 \mathrm{CBE}$ & $94 \mathrm{a}$ & $109 \mathrm{a}$ & $93 \mathrm{a}$ & $104 \mathrm{a}$ & $76 a$ & $8 \mathrm{~b}$ \\
\hline Pro/Cup & $184 \mathrm{a}$ & $182 \mathrm{a}$ & $164 \mathrm{ab}$ & $128 \mathrm{bc}$ & $125 \mathrm{c}$ & $6 \mathrm{~d}$ \\
\hline SR 1020 & $177 \mathrm{a}$ & $192 \mathrm{a}$ & $164 \mathrm{ab}$ & $133 \mathrm{bc}$ & $104 \mathrm{c}$ & $1 \mathrm{~d}$ \\
\hline National & $22 \mathrm{bc}$ & $32 \mathrm{~b}$ & $57 \mathrm{a}$ & $53 a$ & $58 \mathrm{a}$ & $3 c$ \\
\hline
\end{tabular}

${ }^{y}$ Subplots treated on 25 June with $0.3 \mathrm{~kg}$ of cyproconazole per ha.

${ }^{\mathrm{z}}$ Means within a row (=cultivar) followed by the same letter are not significantly different using the Waller-Duncan $k$-ratio $t$ test $(k=100, P=0.05)$. 
The ability of creeping bentgrass cultivars to recover following dollar spot outbreaks under field conditions appears to be a complex, variable attribute. Only one cultivar (SR 1020) exhibited the same recovery pattern in each of 3 years; 10 of 15 cultivars exhibited the same recovery pattern in 2 of the 3 years of testing. We found that the ability of cultivars to recover from dollar spot varied under different environmental conditions. We postulate that recuperative potential also varies under different agronomic management regimes. While recovery was found to vary from year to year, the ability to recover quickly from a disease outbreak could be a valuable varietal trait, particularly if the cultivar possesses other important traits but inadequate levels of resistance to a particular pathogen. The potential for quick recovery from disease would be especially valuable if it can sometimes occur without need for a curative fungicide application, as was found with several cultivars.

\section{ACKNOWLEDGMENTS}

We thank Tom Priddy for providing weather data, Brian Smith and Suyen Leak for statistical advice, and John R. Hartman for reviewing the manuscript.
LITERATURE CITED

1. Anonymous. 1994. National Bentgrass Test 1989 (Fairway/Tee): Final Report 1990-93. National Turfgrass Evaluation Program NTEP No. 94-14.

2. Anonymous. 1994. National Bentgrass Test 1989 (Modified Soil - Green): Final Report 1990-93. National Turfgrass Evaluation Program NTEP No. 94-15.

3. Anonymous. 1994. National Bentgrass Test 1989 (Native Soil - Green): Final Report 1990-93. National Turfgrass Evaluation Program NTEP No. 94-16.

4. Beard, J. B. 1973. Turfgrass: Science and Culture. Prentice-Hall, Inc., Englewood Cliffs, NJ.

5. Burpee, L. L. 1992. Assessment of resistance to Rhizoctonia solani in tall fescue based on disease progress and crop recovery. Plant Dis. 76:1065-1068.

6. Burpee, L. L. 1993. A Guide to Integrated Control of Turfgrass Diseases. Vol. I, Cool Season Turfgrasses. GCSAA Press, Lawrence, KS.

7. DiPaola, J. M., and Beard, J. B. 1992. Physiological effects of temperature stress. Pages 231-267 in: Turfgrass-Agronomy Monograph No. 32. D. V. Waddington, R. N. Carrow, and R. C. Shearman, eds. ASACSSA-SSSA, Madison, WI.

8. Doney, J. C., Vincelli, P. C., and Powell, A. J. 1992. Reactions of bentgrasses to dollar spot and brown patch, 1991. Biol. Cult. Tests Control Plant Dis. 7:101.

9. Doney, J. C., Vincelli, P. C., and Powell, A. J. 1992. Variation among bentgrasses in their ability to recover from dollar spot and brown patch, 1991. Biol. Cult. Tests Control Plant Dis. 7:102.

10. Doney, J. C., Vincelli, P. C., and Powell, A. J. 1993. Reactions of bentgrasses to dollar spot and brown patch, 1992. Biol. Cult. Tests Control Plant Dis. 8:118.

11. Doney, J. C., Vincelli, P. C., and Powell, A. J. 1994. Reactions of bentgrasses to dollar spot, 1993. Biol. Cult. Tests Control Plant Dis. 9:146.

12. Doney, J. C., Vincelli, P. C., and Powell, A. J. 1994. Variation among bentgrasses in their ability to recover from dollar spot, 1993. Biol. Cult. Tests Control Plant Dis. 9:147.

13. Kuehl, R. O. 1994. Statistical Principles of Research Design and Analysis. Duxbury Press, Belmont, MA.

14. Metz, S. P., Colbaugh, P. F., and Engelke, M. C. 1994. Rhizoctonia blight on inoculated zoysiagrasses. Biol. Cult. Tests Control Plan Dis. 9:158.

15. Neter, J., Wasserman, W., and Kutner, M. H. 1983. Applied Linear Regression Models. Irwin, Inc., Homewood, IL.

16. Ott, L. 1977. Introduction to Statistical Methods and Data Analysis. Duxbury Press, North Scituate, RI.

17. Smiley, R. W., Dernoeden, P. H., and Clarke, B. B. 1992. Compendium of Turfgrass Diseases. 2nd ed. American Phytopathological Society, St. Paul, MN.

18. Smith, J. D., Jackson, N., and Woolhouse, A. R. 1989. Fungal Diseases of Amenity Tur Grasses. 3rd ed. E. \& F. Spon Ltd., London.

19. Vargas, J. M., Jr. 1994. Management of Turfgrass Diseases. 2nd ed. CRC Press, Inc., Boca Raton, FL. 